\title{
Perbandingan Aktivitas Antimikroba Ekstrak Etanol dari Tiga Spesies Ganoderma Asal Pulau Lombok
}

\author{
Comparison of Antimicrobial Activities of Ethanol Extract from Three \\ Species of Ganoderma Original Lombok Island
}

\author{
Faturrahman $^{* 1}$, Sukiman ${ }^{1,3}$, Bambang Fajar Suryadi ${ }^{1}$, Sarkono ${ }^{1,2}$, Ernin Hidayati ${ }^{1,2}$ \\ ${ }^{1}$ Department of Biology, Faculty of Mathematics and Natural Sciences, Mataram University, \\ Jl. Majapahit 62, Mataram 83125, West Nusa Tenggara, Indonesia. Telp/fax +62-370-646506. \\ ${ }^{2}$ Microbial Technology Laboratory, Faculty of Mathematics and Natural Sciences, MataramUniversity \\ ${ }^{3}$ Plant Sistemathic Laboratory, Faculty of Mathematics and Natural Sciences, MataramUniversity \\ *corresponding author, email: fatur@unram.ac.id
}

Manuscript received: 27-11-2020. Accepted: 21-03-2021

\begin{abstract}
ABSTRAK
Penggunaan antibiotic merupakan salah satu cara paling utama untuk mengatasi penyebaran dan pengobatan infeksi mikroba patogen. Pencarian sumber antibiotika baru terus dilakukan untuk mengantisipasi munculnya resistensi mikroba. Salah satu sumber daya alam yang berpotensi sebagai sumber antimikroba adalah anggota makrofungi dari Genus Ganoderma. Tujuan dari penelitian ini adalah untuk mengevaluasi kinerja antimikroba dari ekstrak etanol Ganoderma lucidum, G. applanatum dan Ganorderma sp. terhadap fungi (Candida albicans dan Cryptococcus neoformans), bakteri gram positif (Bacillus cereus dan Staphylococcus aureus) dan gram negatif (Escherichia coli dan Shigella sp.). Sampel makrofungi diambil dari kawasan hutan TWA Kerandangan, TWA Suranadi, TWA Nuraksa Sesaot, TWA Lemor dan Hutan Pusuk. Tahapan metode yang dilakukan adalah koleksi sampel, preparasi sampel, ekstraksi, dan pengujian aktivitas antimikroba menggunakan metode sumuran. Konsentrasi ekstrak etanol untuk pengujian adalah 20\%, 40\%, 60\% dan $80 \%$. Hasil penelitian menunjukkan bahwa ketiga spesies Ganoderma memiliki aktivitas antifungi dan antibakteri dan perbedaan tingkat konsentrasi memberikan pengaruh terhadap daya hambat. Besarnya zona hambat berbanding lurus dengan semakin tingginya konsentrasi ekstrak. Aktivitas antimikroba dari ekstrak etanol G. lucidum lebih tinggi bila dibandingkan dengan G. applanatum dan Ganoderma sp. baik itu terhadap fungi (Candida albicans dan Cryptococcus neoformans) maupun bakteri uji gram positif maupun gram negatif. Selain itu, G. applanatum memperlihatkan daya hambat yang sangat lemah terhadap kedua kelompok bakteri uji.
\end{abstract}

Kata kunci: candidiasis; cryptococcosis; infeksi penyerta; maserasi; patogen

ABSTRACT
The use of antibiotics is one of the most important ways to deal with the spread and treatment of
pathogenic microbial infections. The search for new antibiotic sources continues to be carried out to 
anticipate the emergence of microbial resistance. One of the natural resources that has the potential as an antimicrobial source is a member of the macrofungi of the Genus Ganoderma. The purpose of this study was to evaluate the antimicrobial performance of the ethanol extracts of Ganoderma lucidum, G. applanatum dan Ganorderma sp. against fungi (Candida albicans dan Cryptococcus neoformans), gram positive bacteria (Bacillus cereus dan Staphylococcus aureus) and gram negative bacteria (Escherichia coli dan Shigella sp.). Macrofungi samples were taken from the forest area of Nature Tourism Park (TWA) Gunung Tunak, TWA Kerandangan, TWA Suranadi, TWA Nuraksa Sesaot, TWA Lemor and Pusuk forest. The stages of the method performed are sample collection, sample preparation, extraction, and testing of antimicrobial activity using the well difusion method. The ethanol extract concentrations for testing were $20 \%, 40 \%, 60 \%$ and $80 \%$. The results showed that the three Ganoderma species had anti-fungal and antibacterial activity and that different levels of concentration had an effect on inhibition. The size of the inhibition zone is directly proportional to the higher the extract concentration. The antimicrobial activity of the ethanol extract of G. lucidum was higher when compared to G. applanatum and Ganoderma sp. both against fungi (Candida albicans and Cryptococcus neoformans) as well as against gram-positive and gram-negative test bacteria. In addition, G. applanatum showed very weak inhibition against both groups of tested bacteria.

Key words: candidiasis; cryptococcosis; comorbid infections; macerations; pathogens

\section{PENDAHULUAN}

Sampai abad 21, penyakit infeksi tetap menjadi kontributor morbiditas dan mortalitas yang cukup besar bukan hanya di negara berkembang bahkan juga di negara maju. Penyakit infeksi oleh bakteri yang dahulu dianggap "selesai" ditangani dengan baik, rupanya menjadi tantangan baru seiring dengan berkembangnya galur bakteri resisten multi obat (Suwarto, 2014).

Bukan hanya itu, penyakit jamur telah merenggut lebih dari 1,5 juta jiwa dan mempengaruhi lebih dari satu miliar orang. Namun, penyakit infeksi jamur masih menjadi topik yang diabaikan oleh otoritas kesehatan masyarakat meskipun sebagian besar kematian akibat penyakit jamur dapat dihindari. Infeksi jamur serius terjadi sebagai akibat dari masalah kesehatan lainnya termasuk asma, AIDS, kanker, transplantasi organ dan terapi kortikosteroid (Bongomin et al., 2017; Rodrigues \& Nosanchuk, 2020)

Penyakit yang disebabkan fungi juga merupakan infeksi penyerta yang paling sering ditemui pada penderita AIDS terutama kandidosis yang disebabkan oleh Candida sp., kriptokokkosis oleh Cryptoccocus neoformans, aspergillosis oleh Aspergillus sp., dan histoplasmosis oleh fungi patogen yaitu Histoplasma capsulatum (Colombo et al., 2013). Ketiga fungi pertama bersifat oportunis. Infeksi parasit dan fungi yang mengenai penderita AIDS akan meningkatkan morbiditas dan mortalitas.

Penggunaan antibiotik adalah salah satu cara untuk mengatasi penyebaran infeksi tersebut. Antibiotik sebagai obat untuk menanggulangi penyakit infeksi, penggunaannya harus rasional, tepat dan aman. Penggunaan antibiotik yang tidak rasional akan menimbulkan dampak negatif, seperti terjadinya kekebalan mikroorganisme terhadap beberapa antibiotik, meningkatnya efek samping obat (Pratiwi, 2017)

Penelitian terhadap aktivitas suatu senyawa sebagai antimikroba merupakan suatu langkah awal untuk memberikan informasi penting sebagai upaya penanggulangan suatu resistensi penyakit yang disebabkan oleh bakteri dan fungi. Beberapa jenis fungi terutama dari 
genera Ganoderma telah lama diketahui sebagai sumber obat karena kandungan senyawa bioaktifnya (Tata \& Lestari, 2010; Faturrahman \& Sulastri, 2018).

Kajian mengenai kandungan bioaktif dan potensi Ganoderma yang menghuni kawasan hutan pulau Lombok sebagai sumber obat belum banyak dilakukan. Menurut Monk et al., (1997), Pulau Lombok merupakan salah satu pulau di kawasan Kepulauan Sunda Kecil yang memiliki kawasan hutan hujan tropis dataran rendah serta kawasan hutan hujan semi-evergreen yang dapat ditemukan di Gunung Rinjani. Hutan di Pulau Lombok termasuk dalam kategori hutan hujan yang memiliki keanekaragaman hayati tinggi termasuk didalamnya keanekaragaman jenis fungi.

Kekhasan letak geografis Pulau Lombok yang berada dalam jalur peralihan Wallacea Barat dan Wallacea Timur memungkinkan ditemukannya spesies-spesies hewan, tumbuhan maupun mikroorganisme yang bersifat unik. Karakteristik yang unik ini diduga mempengaruhi kandungan dan komposisi bioaktif Ganoderma. Hal ini dimungkin terjadi karena karakter tanaman inang Ganoderma yang berada pada zona peralihan mewakili sifat-sifat yang terdapat pada kedua zona pengapitnya.

Paper ini memaparkan hasil penelitian tentang aktivitas antimikroba dari ekstraks etanol dari Ganoderma lucidum, Ganoderma applanatum, dan Ganoderma sp. yang berasal dari kawasan hutan Taman Wisata Alam (TWA) Kerandangan, TWA Suranadi, TWA Nuraksa Sesaot, TWA Lemor, TWA Gunung Tunak, dan Hutan Pusuk dalam menghambat pertumbuhan jamur (Candida albicans dan Cryptoccocus neoformans), bakteri gram positif (Bacillus cereus dan Staphylococcus aureus) dan gram negatif (Escherichia coli dan Shigella sp.).

\section{BAHAN DAN METODE}

Persiapan sampel

Sampel Ganoderma lucidum, Ganoderma applanatum, dan Ganoderma sp. diambil dari kawasan hutan Taman Wisata Alam (TWA) Suranadi, TWA Sesaot, TWA Kerandangan, TWA Lemor, TWA Gunung Tunak, dan Hutan Pusuk. Pengambilan dilakukan dengan cara memotong tubuh buah jamur Ganoderma lalu dimasukkan ke dalam zip lock atau plastik steril (Muspiah, et al., 2016). Adapun distribusi lokasi penemuan ketiga sampel Ganoderma dapat dilihat pada Tabel 1

Table 1. Distribusi lokasi penemuan Ganoderma lucidum, Ganoderma applanatum, dan Ganoderma sp.

\begin{tabular}{lll}
\hline Spesies & Lokasi & Inang \\
\hline Ganoderma applanatum & Hutan Pusuk, TWA Kerandangan, & BWA Lemor, TWA Gunung Tunak, \\
& TWA Suranadi & mati, batang pohon hidup \\
Ganoderma lucidum & $\begin{array}{l}\text { TWA Gunung Tunak, TWA Suranadi } \\
\text { \& Hutan Pusuk }\end{array}$ & $\begin{array}{l}\text { Batang atau cabang pohon } \\
\text { mati }\end{array}$ \\
Ganoderma sp & TWA Suranadi & Batang pohon hidup \\
\hline
\end{tabular}


Selanjutnya sampel dibersihkan dari segala kotoran yang menempel kemudian dikeringanginkan dan dipotong kecil-kecil lalu dioven pada suhu $40^{\circ} \mathrm{C}$ sampai kering.

\section{Ekstraksi sampel}

Sampel diblender dan dimaserasi menggunakan pelarut etanol 95\% selama 5 hari dalam tabung vial yang ditutup rapat dengan pengadukan secara berkala dan dilakukan setiap hari (Raharjo, 2013). Setelah itu disaring dan pelarut diuapkan menggunakan evaporator. Setelah itu, hasil maserasi disaring sehingga diperoleh maserat. Maserat etanol yang diperoleh kemudian dipekatkan menggunakan evaporator dengan suhu $40^{\circ} \mathrm{C}$. Ekstrak kental dilarutkan dengan menggunakan DMSO 50\% sesuai konsentrasi untuk pengujian yaitu 20\%, 40\%, 60\%, dan $80 \%$ (Handrianto, 2018).

\section{Persentase Rendeman Ekstrak}

Rendemen merupakan persentase bagian bahan baku yang dapat digunakan atau dimanfaatkan dengan total bahan baku, sehingga perhitungan persentase rendemen sebagai berikut (Trinanda, 2012):

$$
\% \text { Rendemen }=\frac{\text { Berat Ekstrak } \operatorname{Kental}(g)}{\text { Berat Simplisia }(g)} \times 100 \%
$$

\section{Pembuatan Media Sabouraud Dextrose Agar (SDA)}

Media yang digunakan dalam penelitian ini adalah Sabouraud Dextrose Agar (SDA) dengan komposisi 27,5 g Dextrose, 12,5 g Nutrien Agar, dan 5 g Peptone dicampur dengan $500 \mathrm{~mL}$ aquades dalam erlenmeyer kemudian dipanaskan sambil diaduk hingga mendidih di atas hot plate. Setelah mendidih, media tersebut disterilkan dengan autoklaf pada suhu $121^{\circ} \mathrm{C}$ dan tekanan 2 atm selama 30 menit.

\section{Peremajaan Fungi Uji}

Peremajaan fungi uji (Candida albicans) dilakukan dengan cara: isolat murni yang ada, diambil satu ose selanjutnya digoreskan pada medium SDA di dalam cawan petri menggunakan metode gores kuadran dan diinkubasi pada suhu $30^{\circ}$ Cselama 24 jam.

\section{Uji Bioaktivitas Ekstrak Ganoderma Menggunakan Metode Sumuran}

Pengujian bioaktivitas antifungi ini dilakukan menggunakan metode difusi agar yaitu metode sumuran. Metode ini digunakan untuk memastikan adanya aktivitas antifungi yang terdapat pada Ganoderma sp. Parameter yang digunakan adalah zona hambat.

Larutan ekstrak dibuat dengan beberapa konsentrasi yaitu 20\%, 40\%, 60\% dan 80\% v/v menggunakan pelarut DMSO 50\%. Suspensi jamur uji yang telah disesuaikan dengan kekeruhan Mc Farland digoreskan menggunakan kapas swab di atas media SDA hingga rata (menutupi seluruh permukaan media uji), kemudian dibuat lubang pada media dengan diameter $7 \mathrm{~mm}$ menggunakan pelubang steril. Setiap sumuran dipipetkan sebanyak $100 \mu \mathrm{L}$ ekstrak dari tiap-tiap konsentrasi yang telah dibuat. Setelah itu diinkubasi pada suhu $30^{\circ} \mathrm{C}$. Pengulangan dilakukan sebanyak tiga kali. Kontrol positif yang digunakan berupa antibiotik sintesis metronidazol $200 \mathrm{mg}$. 


\section{Kategori Penghambatan}

Penentuan kategori respon hambatan pertumbuhan menurut Ardiansyah (2007) dapat dilihat pada Tabel 1

Tabel 2 Klasifikasi respon hambatan pertumbuhan fungi

\begin{tabular}{cc}
\hline Diameter Zona Hambat & Respon Hambatan Pertumbuhan \\
\hline$>20 \mathrm{~mm}$ & Sangat Kuat \\
$16-20 \mathrm{~mm}$ & Kuat \\
$10-15 \mathrm{~mm}$ & Sedang \\
$<10 \mathrm{~mm}$ & Lemah \\
\hline
\end{tabular}

\section{HASIL DAN PEMBAHASAN}

\section{Ekstrak Etanol Tiga Spesies Ganoderma}

Preparasi sampel dari tiga spesies Ganoderma diperoleh sampel kering (simplisia) dalam bentuk serbuk, dengan tujuan memperluas permukaan sampel yang kontak dengan pelarut sehingga hasil yag didapatkan lebih besar dalam ekstraksi. Tabel 3 berikut adalah jumlah simplisia beserta persentase rendaman yang diperoleh dari hasil ekstraksi.

Tabel 3. Persentase Rendemen Ekstrak Etanol dari Tiga Spesies Ganoderma

\begin{tabular}{lccc}
\hline Spesies Ganoderma & $\begin{array}{c}\text { Berat simplisia } \\
(\mathbf{g})\end{array}$ & $\begin{array}{c}\text { Hasil Ekstraksi } \\
(\mathbf{g})\end{array}$ & $\begin{array}{c}\text { Rendemen Ekstrak } \\
(\mathbf{\%})\end{array}$ \\
\hline Ganoderma applanatum & 192,8 & 6 & 3,11 \\
Ganoderma lucidum & 209,6 & 5 & 2,39 \\
Ganoderma sp. & 182,3 & 4 & 2,19 \\
\hline
\end{tabular}

Tabel 3 diatas menunjukkan bahwa hasil ekstraksi yang didapatkan sangat sedikit. Sehingga untuk memperoleh ekstrak yang lebih banyak lagi dibutuhkan sampel yang cukup banyak pula. Untuk Ganoderma applanatum hasil ekstraksi yang didapatkan berupa larutan yang sangat kental dengan warna coklat kehitaman, Ganoderma lucidum berupa larutan kental berwarna coklat tua dan Ganoderma sp. berupa larutan kental berwarna coklat kekuningan serta terdapat gumpalan-gumpalan berwarna coklat tua.

Kemampuan pelarut etanol dalam mengekstrak senyawa-senyawa yang terkandung dalam ketiga spesies Ganoderma lebih kecil dibandingkan dengan kemampuan pelarut etanol dalam mengekstrak senyawa-senyawa yang terkandung dalam jamur yang lain. Falakh (2008) mendapatkan rendemen ekstrak etanol jamur kuping hitam (Auricularia polytricha) hasil ekstrak maserasi yaitu 14,77\% dari berat simplisia 256,0011 gr. Selain itu, Luciana (2015) memperoleh rendemen ektraks etanol sebesar $10.10 \%$ dari $200 \mathrm{~g}$ simplisia jamur tiram putih yang dianalisis. Sukmawati et al (2019) memperoleh rendemen sebesar 13,08\% atau 143,93g dari berat simplisia $1100 \mathrm{~g}$.

Besar kecilnya nilai rendemen menunjukkan keefektifan proses ekstraksi. Efektivitas proses ekstraksi dipengaruhi oleh jenis pelarut yang digunakan sebagai penyari, ukuran partikel simplisia, metode dan lamanya ekstraksi (Permawati, 2008). Sehingga dapat dilihat pada tabel 
bahwa ketiga jenis Ganoderma menghasilkan ekstrak dengan persentase rendemen dibawah $5 \%$.

Ekstraksi dengan metode maserasi tidak melibatkan pemanasan sehingga perubahanperubahan senyawa yang terkandung dapat dihindari dan tujuan dari pengadukan secara berkala selama maserasi adalah untuk menghindari memadatnya serbuk sehingga pelarut sulit menembus bahan dan kesulitan mengambil senyawa-senyawa aktif.

Etanol digunakan sebagai pelarut karena pelarut yang digunakan harus memiliki sifat kepolaritasan yang sama dengan senyawa yang akan ditarik. Etanol dapat menarik senyawa metabolit sekunder terutama dapat mengoptimalkan penarikan beberapa senyawa dengan berat molekul rendah seperti saponin dan flavanoid dimana kedua diantaranya merupakan senyawa antifungi (Kurniawan, 2015)

\section{Aktivitas Antimikroba Ekstrak Etanol Tiga Spesies Ganoderma}

Ekstrak etanol kental yang didapatkan dari ekstraksi maserasi, kemudian dilakukan pengujian untuk mengetahui apakah ekstrak etanol mempunyai aktivitas antifungi atau tidak. Masing-masing ekstrak dibuat konsentrasi sebesar 20\%, 40\%, 60\% dan 80\% menggunakan pelarut aquades untuk Ganoderma applanatum dan Ganoderma lucidum, sedangkan pelarut yang digunakan untuk Ganoderma sp. adalah Dimetil Sulfoksida (DMSO) 50\%. Hal ini dilakukan karena ekstrak kental dari Ganoderma sp. tidak bisa larut sepenuhnya menggunakan aquades. DMSO digunakan sebagai pelarut untuk kontrol negatif, karena DMSO merupakan pelarut polar aprotik, titik didihnya tinggi sehingga menguap secara perlahan pada tekanan udara normal, larutan tidak berwarna yang dapat melarutkan senyawa polar dan nonpolar yang mempunyai range luas dari pelarut organik seperti halnya air dan tidak mempengaruhi aktivitas biologis dari mikroba (Effendy, 2013).

Hasil pengukuran diameter zona hambat ekstrak etanol ketiga spesies Ganoderma terhadap Candida albicans, Cryptococcus neoformans, Staphilococcus aureus, Bacillus cereus, Echerichia coli and Shigella sp. disajikan pada Tabel 4.

Tabel 4. Diameter zona hambat ekstrak etanol ketiga spesis Ganoderma terhadap mikroba uji

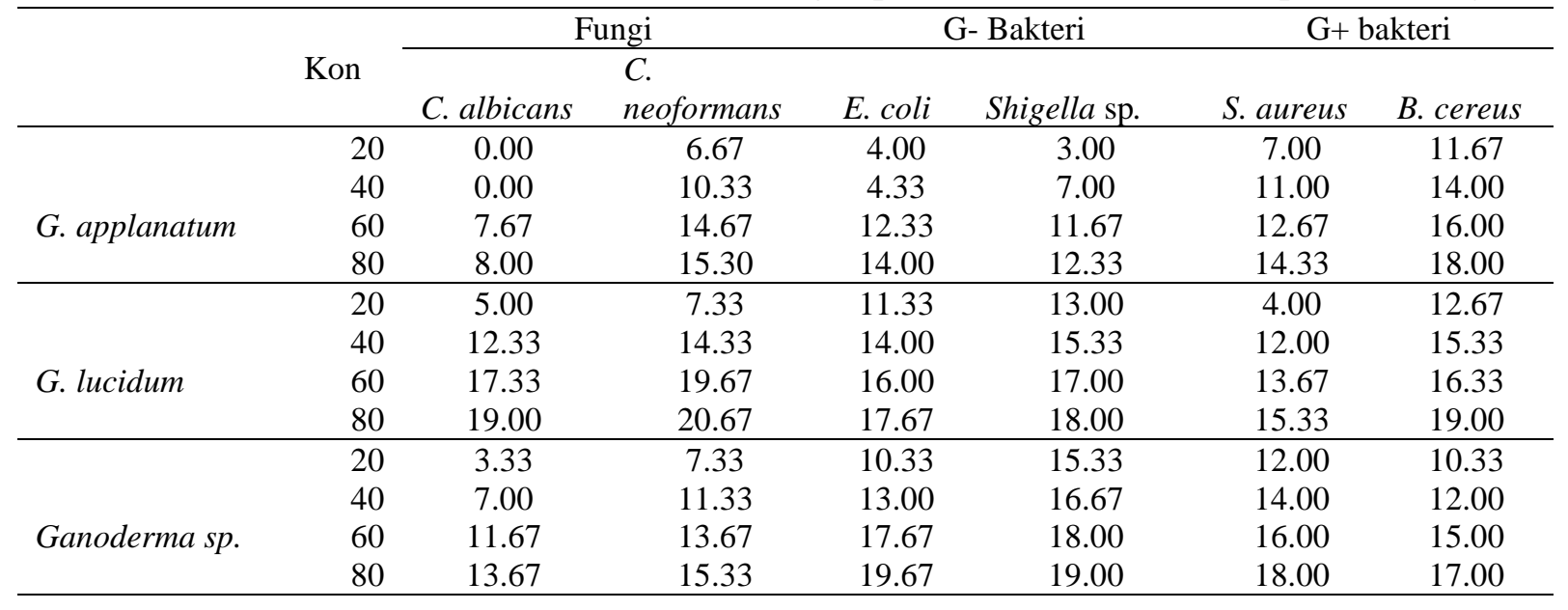


Secara umum dari data pada Tabel 4 memperlihatkan bahwa aktivitas antimikroba dari paling rendah diperoleh oleh ekstrak etanol $G$. applanatum terhadap fungi $C$. albicans yaitu $0 \mathrm{~mm}$ pada konsentrasi $20 \%$ dan yang paling tinggi dicapai oleh G.lucidum terhadap C. neoformans yaitu $20.67 \mathrm{~mm}$ pada konsentrasi $80 \%$.

Hasil pengukuran diameter zona hambat ekstrak etanol Ganoderma applanatum menunjukkan bahwa ekstrak etanol G. applanatum memiliki daya hambat lemah terhadap bakteri gram negatif (E.coli) pada konsentrasi $20 \%$ dan $40 \%$, daya hambat kuat pada konsentrasi $60 \%$ dan $80 \%$. Ekstrak etanol G. applanatum memiliki daya hambat lemah terhadap bakteri gram negatif (Shigella sp.) pada konsentrasi $20 \%$, daya hambat sedang pada konsentrasi $40 \%$, daya hambat kuat pada konsentrasi $60 \%$ dan $80 \%$. Ekstrak etanol $G$. applanatum memiliki daya hambat sedang terhadap bakteri gram positif ( $S$. aureus) pada konsentrasi 20\%, daya hambat kuat pada konsentrasi 40\%, 60\% dan 80\%. Ekstrak etanol $G$. applanatum memiliki daya hambat kuat terhadap bakteri gram positif (B. cereus) pada semua konsentrasi.

Hasil pengukuran diameter zona hambat ekstrak etanol Ganoderma lucidum menunjukkan bahwa ekstrak etanol G. lucidum memiliki daya hambat kuat terhadap bakteri gram negatif (E.coli dan Shigella sp.) serta bakteri gram positif (B. cereus) pada semua konsentrasi. Sedangkan pada bakteri gram positif ( $S$. aureus) memiliki daya hambat lemah pada konsentrasi 20\%, daya hambat kuat pada konsentrasi 40\%, 60\% dan 80\%. Sementaraiitu, diameter zona hambat ekstrak etanol Ganoderma sp. menunjukkan bahwa ekstrak etanol Ganoderma sp. memiliki daya hambat kuat terhadap bakteri gram negatif (E.coli dan Shigella sp.) serta bakteri gram positif ( $S$. aureus dan B. cereus) pada semua kosentrasi

Gambar 2, 3, dan 4 di bawah ini adalah aktivitas penghambatan ekstrak etanol dari ketiga spesies Ganoderma terhadap kelompok jamur uji (Candida albicans dan Cryptococcus neoformans), bakteri uji gram positif (Staphilococcus aureus dan Bacillus cereus) dan bakteri uni gram negatif (Echerichia coli and Shigella sp.).

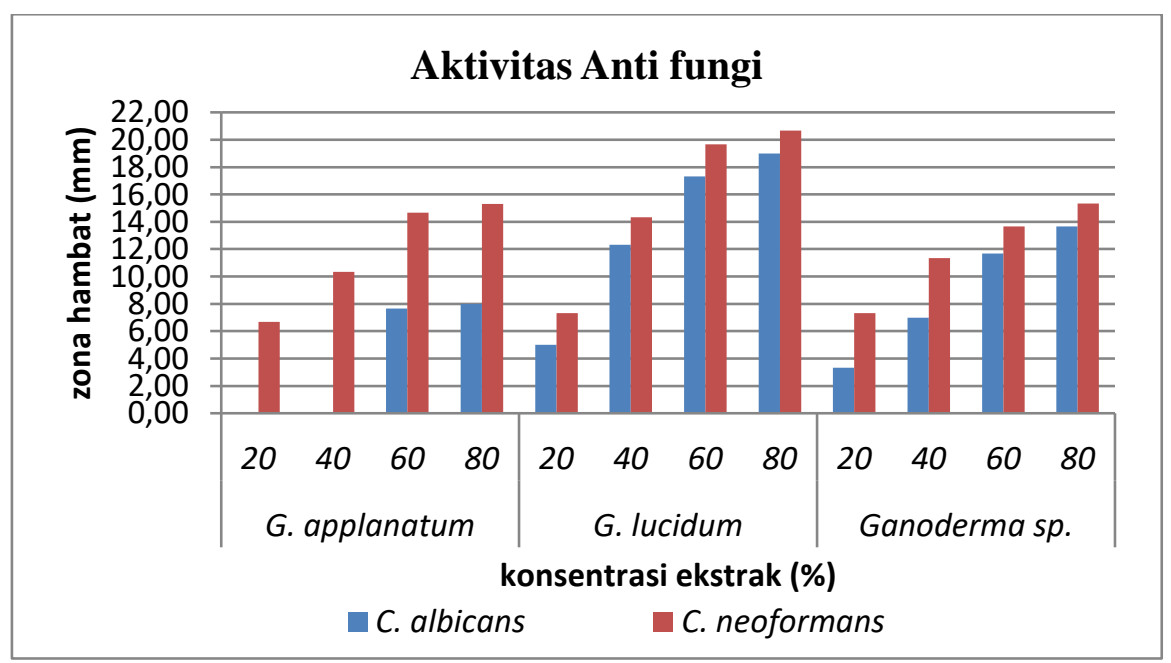

Gambar 2. Grafik hasil uji aktivitas antifungi ketiga ekstrak etanol Ganoderma terhadap Candida albicans dan Cryptococcus neoformans, pengulangan dilakukan sebanyak 3 kali 
Gambar 2 menunjukkan bahwa ekstrak etanol Ganoderma lucidum memiliki aktivitas antifungi yang lebih tinggi bila dibandingkan G.applanatum dan Ganoderma sp., baik itu terhadap Candida albicans dan Cryptococcus neoformans. Namun, aktivitas antifungi dari ketiga ekstrak etanol Ganoderma lebih efektif terhadap Cryptococcus neoformans dibandingkan terhadap C. albicans.

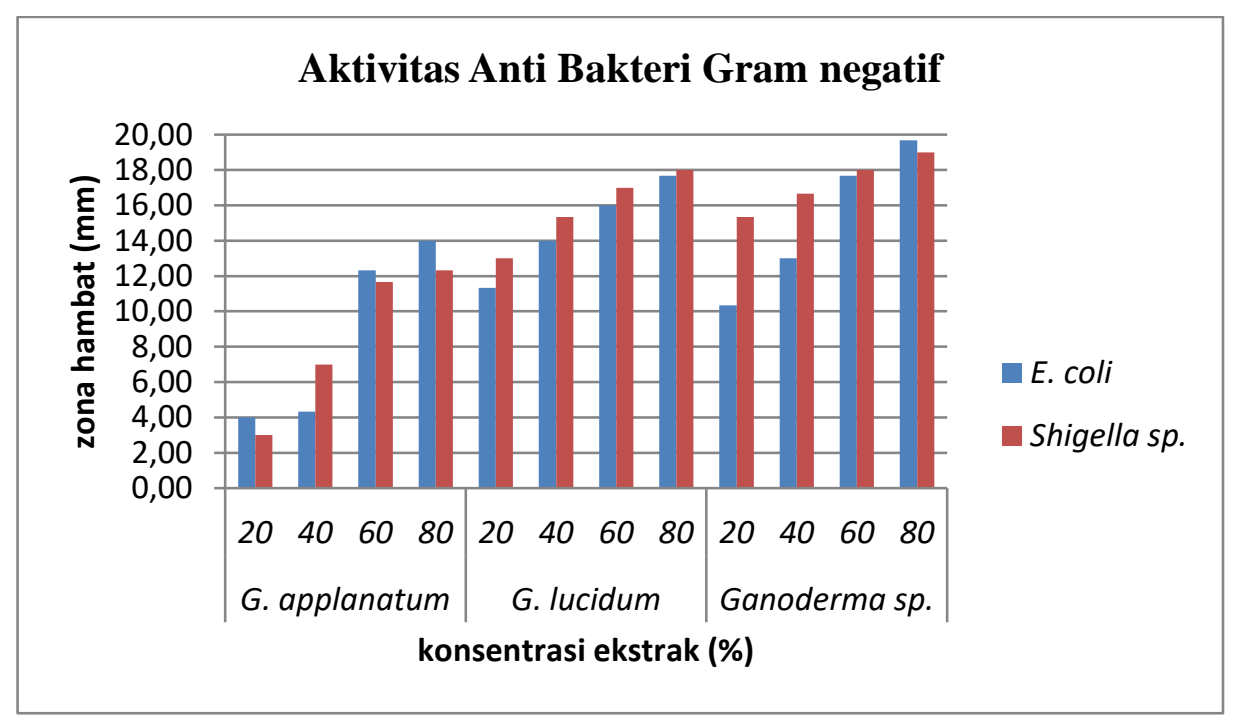

Gambar 3. Grafik hasil uji aktivitas antibakteri ketiga ekstrak etanol Ganoderma terhadap Echerichia coli and Shigella sp., pengulangan dilakukan sebanyak 3 kali

Gambar 3 memperlihatkan bahwa aktivitas antimikroba Ganoderma lucidum dan Ganoderma sp memiliki aktivitas antibakteri gram negatif yang lebih tinggi bila dibandingkan G. applanatum.

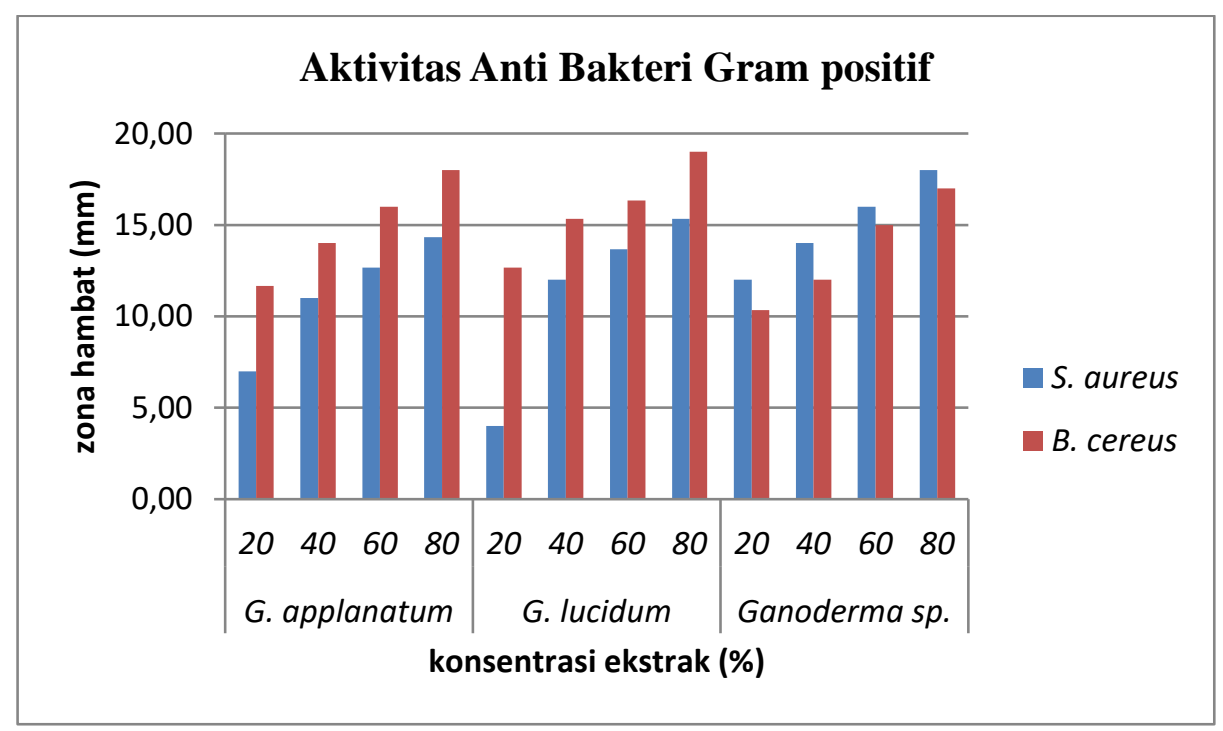

Gambar 4. Grafik Hasil uji aktivitas antibakteri ketiga ekstrak etanol Ganoderma terhadap Staphilococcus aureus dan Bacillus cereus, pengulangan dilakukan sebanyak 3 kali 
Gambar 4 menunjukkan bahwa aktivitas ekstrak etanol dari ketiga ganoderma cukup baik terhadap bakteri gram positif. Akan tetapi, Ganoderma lucidum dan G. applanatum lebih baik dalam menghambat pertumbuhan Bacillus cereus dibandingkan penghambatannya terhadap Staphylococcus aureus. Sementara Ganoderma sp. lebih kuat aktivitas penghambatanya terhadap B. cereus bila dibandingkan $S$. aureus.

Dari gambar 2,3 dan 4 tersebut diatas dapat dilihat pula bahwa penambahan tingkat konsentrasi ekstrak memberikan pengaruh terhadap diameter zona hambat yang terbentuk. Semakin tinggi tingkat konsentrasi ekstrak, semakin besar pula zona hambat yang terbentuk, yang artinya adalah tingginya konsentrasi berbanding lurus dengan besarnya zona hambat.

Hal ini terjadi karena pada konsentrasi yang tinggi, senyawa aktif yang terkandung lebih banyak dibanding senyawa aktif yang terkandung didalam larutan yang konsentrasinya lebih rendah. Oleh karenanya, konsentrasi yang lebih tinggi daya hambatnya lebih besar, dan tingkat kosentrasi ekstrak yang daya hambatnya paling besar adalah konsentrasi yang paling tinggi yaitu $80 \%$. Hasil penelitian Swati et al., (2018) juga menunjukkan bahwa semakin tinggi konsentrasi ekstrak G. lucidum maka penghambatan terhadap pertumbuhan C. albicans makin tinggi. Hal ini sesuai dengan pendapat Triastinurmiatiningsih (2015) yang menyatakan bahwa ukuran dari zona hambat dipengaruhi oleh tingkat sensitivitas dari organisme uji, media kultur dan kondisi inkubasi, kecepatan difusi dari senyawa antijamur dan konsentrasi senyawa antijamur.

Selain itu, grafik diatas juga menunjukkan bahwa uji penghambatan antifungi oleh ekstrak etanol mempunyai kemampuan dalam penghambatan fungi uji yaitu Candida albicans dan Cryptococcus neoformans, dimana ketiga ekstrak lebih efektif terhadap Cryptococcus neoformans dibanding Candida albicans. Hal ini terjadi karena Candida albicans merupakan salah satu mikrobiota normal yang sering terpapar oleh bahan kimia (seperti antibiotik) sehingga mengalami mutasi dan berpengaruh secara fisiologis (misalnya mengeluarkan senyawa atau yang dapat menetralisir antifungi sehingga menjadi resisten terhadap beberapa senyawa antifungi) ataupun berpengaruh secara morfologi, seperti membentuk kapsul pelindung berupa biofilm. Biofilm merupakan koloni fungi yang membentuk matriks polimer organik yang terdiri dari dua lapisan, yaitu lapisan basal yang tipis yang merupakan lapisan khamir itu sendiri dan lapisan luar yaitu lapisan hifa yang lebih tebal tetapi susunannya lebih renggang (Brand, 2012).

Secara umum dari gambar 2,3 dan 4 menunjukkan bahwa ekstrak etanol dari Ganoderma lucidum memiliki aktivitas antimikroba yang lebih besar baik itu terhadap fungi maupun bakteri uji bila dibanding ekstrak Ganoderma applanatum dan Ganoderma sp. Hal ini diduga karena senyawa aktif sebagai antifungi yang terkandung didalam Ganoderma lucidum memiliki jumlah yang lebih banyak dibandingkan dengan kedua jamur Ganoderma lainnya. Jamur ini juga sudah digunakan cukup lama sebagai obat untuk berbagai macam penyakit. Hasil penelitian ini sejalan dengan hasil penelitian Kumar et al. (2018) yang menunjukkan bahwa Ganoderma lucidum memiliki aktivitas antifungal terhadap Candida albicans, Aspergillus flavus, A. Fumigates dan Crytococcus neoformans.

Dari semua hasil diatas, diketahui bahwa ketiga spesies Ganoderma positif mengandung senyawa-senyawa antimikroba berupa yaitu terpenoid, flavanoid, tannin, alkaloid dan steroid 
(Muhsin et al., 2011 dan Ede et al., 2012; Kumar et al., 2018). Gowrie et al., (2014) melaporkan bahwa Ganoderma lucidum mengandung alkaloid, karbohidrat, saponin, protein, asam amino, fitosterol, lemak, triterpenoid, flavonoid, senyawa fenolik dan tanin yang dapat digunakan sebagai antiinflamasi, antibakteri, antikanker dan antioksidan. Senyawa-senyawa antijamur tersebut bekerja seperti halnya antibiotik.

Mekanisme kerja flavanoid dalam menghambat pertumbuhan jamur yakni dengan menyebabkan gangguan permeabilitas membran sel jamur. Gugus hidroksil yang terdapat pada senyawa flavanoid menyebabkan perubahan komponen organik dan transport nutrisi yang akhirnya akan mengakibatkan timbulnya efek toksik terhadap jamur (Raharjo, 2013).

Alkaloid dapat menghambat sintesis asam nukleat dan mempengaruhi ergosterol pada jamur (Alfiah et al. 2015). Namun pada penelitian Maatalah (2012), Alkaloid memberikan efek negatif terhadap pertumbuhan Candida albicans.

Terpenoid dapat melarutkan lipid yang terdapat dalam membran sel jamur dan mengganggu transport nutrisi yang dapat menyebabkan membran sel kekurangan nutrisi sehingga terjadi kerusakan pada sel jamur (Alfiah, 2015).

Mekanisme penghambatan tanin yaitu dengan cara mempengaruhi intregitas dinding sel jamur sehingga transport elektron terganggu yang mengakibatkan pertumbuhan jamur terhambat. Selain itu terjadi penghambatan enzim ekstraseluler jamur oleh tanin, jamur kehilangan substrat yang dibutuhkan untuk pertumbuhan serta mekanisme penghambatan metabolisme langsung melalui gangguan fosforilasi oksidatif atau kehilangan Fe (Scalbert, 1991). Tanin juga dapat menyebabkan denaturasi dan koagulasi protein sel bakteri dan jamur, turunan ini dapat berinteraksi dengan sel mikroba melalui proses absorbsi dengan melibatkan ikatan hidrogen (Siswandono dan Soekarjo, 1995).

Dalam pengujian ini, dibuat kontrol yaitu kontrol positif dan kontrol negatif. Kontrol positif berupa metronidazol untuk antifungi, sedangkan untuk antibakteri digunakan antibiotik Ciprofloxacin. Kontrol digunakan dengan tujuan sebagai pembanding sehingga dapat diketahui apakah ekstrak etanol dari ketiga spesies Ganoderma tersebut mempunyai aktivitas antifungi atau antibakteri yang sama dengan antibiotik sintetik. Sedangkan kontrol negatif digunakan untuk mengetahui apakah larutan yang digunakan memiliki aktivitas antifungi atau tidak. Kontrol negatif berupa aquades dan DMSO 50\%. Hasil uji antimikroba kontrol positif dan negatif dapat dilihat pada Table 5 .

Tabel 5. Hasil uji antimikroba kontrol (+) dan kontrol (-) terhadap fungi dan bakteri

\begin{tabular}{lcccc}
\hline \multirow{2}{*}{ Mikroba Uji } & \multicolumn{2}{c}{ Kontrol (+) (mm) } & \multicolumn{2}{c}{ Kontrol (-) } \\
\cline { 2 - 5 } & Metronidazol & Ciprofloxacin & Aquadest & DMSO 50\% \\
\hline Candida albicans & 11 & - & 0 & 0 \\
Cryptococcus neoformans & 20 & - & 0 & 0 \\
Escherichia coli & - & 22 & 0 & 0 \\
Shigella sp. & - & 26 & 0 & 0 \\
Staphylococcus aureus & - & 25 & 0 & 0 \\
Bacillus cereus & - & 23 & 0 & 0 \\
\hline
\end{tabular}

Berdasarkan tabel diatas, metronidazol membentuk zona hambat yang lebih kecil dibanding rata-rata dari ketiga ekstrak Ganoderma terhadap pertumbuhan Candida albicans. 
Hal ini berarti bahwa ekstrak etanol dari ketiga spesies ganoderma tersebut memiliki kemampuan menghambat pertumbuhan fungi uji yang lebih besar.

Hasil pengukuran diameter zona hambat kontrol menunjukkan bahwa ciprofloxacin (kontrol positif) dapat menghambat pertumbuhan bakteri gram negatif maupun gram positif dan memiliki kekuatan daya hambat yang sangat kuat, sedangkan aquadest dan DMSO 50\% (kontrol negatif) tidak menghasilkan zona hambat.

\section{KESIMPULAN}

Ekstrak etanol Ganoderma lucidum, Ganoderma applanatum dan Ganoderma sp. memiliki aktivitas antijamur dan antibakteri gram positif dan gram negative. Ketiga spesies jamur ganoderma tersebut dapat menghambat pertumbuhan jamur Candida albicans dan Cryptococcus neoformans serta bakteri Staphilococcus aureus, Bacillus cereus, Echerichia coli and Shigella sp.. Ekstrak etanol G. lucidum memiliki aktivitas penghambatan jamur yang lebih tinggi dibandingkan dengan G. applanatum dan Ganoderma sp. dan ketiga ekstrak etanol Ganoderma lebih efektif menghambat $C$. neoformans dibandingkan $C$. albicans. Konsentrasi ekstrak berbanding lurus dengan jumlah zona hambat yang terbentuk. Studi ini membenarkan klaim penggunaan Ganoderma dalam sistem pengobatan tradisional dan komponen bioaktifnya untuk mengobati berbagai penyakit menular yang disebabkan oleh mikroba.

\section{Ucapan Terimakasih}

Peneliti mengucapkan terima kasih kepada Universitas Mataram atas dana yang diberikan melalui penelitian skim Peningkatan Kapasitas tahun 2020 dari dana DIPA BLU-PNBP dengan nomor kontrak 2789/UN18.L1/PP/2020.

\section{DAFTAR PUSTAKA}

Alfiah R.R., Khotimah S., \& Turnip, M. (2015). Efektivitas Ekstrak Metanol Daun Sembung Rambat (Mikania micrantha Kunth) Terhadap Pertumbuhan Jamur Candida albicans. Protobiont Vol. 4 (1) : 52-57

Bongomin, F., Gago, S., Oladele, R. O., \& Denning, D.W. (2017). Global and Multi-National Prevalence of Fungal Diseases-Estimate Precision. J. Fungi, vol 3 no 57; doi:10.3390/jof3040057

Brand A., (2012). Hyphal Growth in Human Fungal Pathogens and Its Role in Virulence. International Journal of Microbiology Volume 2012, Article ID 517529, 11 pages doi:10.1155/2012/517529

Brown, G.D., Denning, D.W., Gow, N.A.R., Levitz, S.M., Netea, M.G., White, T.C. (2012). Hiden Killers: Human Fungal Infections. Sci. Transl. Med. 4, 1-9.

Colombo T.E., Márcia Maria Costa Nunes Soares, bSolange Corrêa Garcia Pires D’Ávillac, Mara Correa Lelles Nogueira, dMargarete Teresa Gottardode Almeida, 2012. Identification of fungal diseases at necropsy. Pathology - Research and Practice. Volume 208, Issue 9, P. 549-552.

Denning, D.W. (2013). Global fungal Burden. Mycoses, vol 56, no 13 
Denning, D.W. (2015). The ambitious " $95-95$ by 2025 " roadmap for the diagnosis and management of fungal diseases. Thorax, 70, 613-614.

Ede, S.O., Olaniru, E., Otimenyin, S., Aguiyi, J.C., \& Ekwere, E.O. (2012). Analgesic and Anti Inflammatory Activities of the Ethanolic Extract of the Mushroom Ganoderma applanatum. Ijrras. Vol.13 (1): 349-352.

Effendy, L. (2013). Potensi Antijamur Kombinasi Ekstrak Etanol Daun Sirih Merah (Piper crocatum Ruiz \& Pav.) dan Kelopak Bunga Rosella (Hibiscus sabdariffa Linn.) terhadap Candida albicans. Jurnal Ilmiah Mahasiswa Universitas Surabaya. Vol. 2(1): $1-10$.

Falakh, S., 2008, Aktivitas Antioksidasi Ekstrak Jamur Kuping Hitam (Auricularia polytricha), [Skripsi], Bogor, Institut Pertanian Bogor.

Faturrahman \& Sulastri, M.P. (2018). Makrofungi di Pulau Lombok. Kiat Abdi Insani. Mataram

Gowrie, U. S., Chathurdevi, G. \& Rani, K. (2014). Evaluation of bioactive potential of basidiocarp extracts of Ganoderma lucidum. International Journal of Pharmaceutical Research \& Allied Sciences, 3(1), 36-46.

Handrianto, P. 2018. Aktivitas Antibakteri Ekstrak Metanol Jamur Lingzhi (Ganoderma lucidum) terhadap Staphylococcus aureus. Journal of Pharmacy and Science: 3 (1): 47-49

Kumar, N., Srikumar, R., Chidambaram, R., \& Reddy, P. (2018). Phytochemical Analysis and Antifungal Activity of Ganoderma lucidum. Indian Journal of Public Health Research \& Development, Vol. 9, No. 12: 1-5

Lusiana 2015. Potensi Antioksidasi Ekstrak Etanol Jamur Tiram Putih (Pleurotus Ostreatus). Jurnal Gradien Vol. 11 No. 1: 1066-1069

Mendling, W., \& Brasch, J. (2012). Guideline vulvovaginal candidosis (2010) of the german society for gynecology and obstetrics, the working group for infections and infectimmunology in gynecology and obstetrics, the german society of dermatology, the board of german dermatologists and the german speaking mycological society. Blackwell Verlag GmbH • Mycoses 55 (Suppl. 3), 1-13.

Muhsin, T.M., Hafiz, A. \& Kawther T.K. (2011). Bioactive Compounds from a Polypore Fungus Ganoderma applanatum (Per s. ex Wallr.) Pat. Jordan Journal of Biological Sciences. Vol 4 (4): 205- 212.

Muspiah, A., Sukiman, \& Faturrahman. (2016). Keragaman Ganodermataceae Dari Beberapa Kawasan Hutan Pulau Lombok. Jurnal Biowallacea 2 (1):54-61

Pratiwi, R.H. (2017). Mekanisme Pertahanan Bakteri Patogen Terhadap Antibiotik. Jurnal ProLife Vole 4 No 3

Raharjo, B., Agitya R., \& Ayu, M.S. (2013). Uji Aktivitas Antijamur Dan Bioautografi Ekstrak Etanol Daun Kelor (Moringa oleifera Lamk.) terhadap Malassezia furfur. Diakses pada tanggal 28 juli 2015 di http://perpusnwu.web.id/karyailmiah/documents/3211.pdf

Rodrigues, M.L. \& Nosanchuk, J.D. (2020). Fungal diseases as neglected pathogens: A wakeup call to public health officials. PLOS Neglected Tropical Diseases. 14(2): e0007964 https://doi.org/10.1371/journal.pntd.0007964 
Suwarto S., 2014. Penyakit Tropik dan Infeksi pada Abad 21: Apakah masih relevan. Jurnal Penyakit Dalam Indonesia, vol 1 (2): 1-2

Sukmawati I.K., Bahri, S., Suwendar, Nurfitria, R.S., 2019. Aktivitas Antibakteri Ekstrak Tiram Putih (Pleurotus ostreatus) terhadap Staphylococcus aureus, Escherichia coli, Pseudomonas aeruginosa, dan Bacillus cereus. Journal of Pharmacopolium, Vol. 2, No. 2: 63-67

Swati, Tiwari, A., Negi, P.S., \& Meena, H.S. (2018). A Comparative evaluation of in vitro anti-inflammatory and antifungal activity of Ganoderma lucidum strains DARL-4 and MS-1. International Journal of Green Pharmacy, vol 12 (1): 126-130

Tata, M. \& Lestari, H. (2010). Potensi Biodiversitas Jamur Obat dan Pangan untuk Biobanking. Laporan Kemajuan Penelitian Insentif TA.

Triastinurmiatiningsih, Yulianti, R., \& Sugiharti, D., (2015). Uji Aktivitas Ekstrak Sargassum crassifolium Sebagai Antifungi Candida albicans. Ekologia, Vol. 15 (1): 22-28. 